\title{
Iron Transport in Mycobacterium smegmatis: The Isolation, Purification and Function of Exochelin MS
}

\author{
By LIONEL P. MACHAM,* MARIS C. STEPHENSON AND \\ COLIN RATLEDGE \\ Department of Biochemistry, University of Hull, Hull HU6 ${ }_{7} R X$
}

(Received 24 January 1977)

\begin{abstract}
The capacity of culture filtrates of Mycobacterium smegmatis growing in iron-deficient medium to solubilize inorganic iron increases throughout the growth phase. When the source of iron, either ferric phosphate or ferritin, was contained within diffusion capsules, bacteria grew unimpeded indicating that freely-diffusible iron chelates were being produced which could support growth. The maximum production of the iron-binding compounds, termed exochelins, occurred with $0.03 \mu \mathrm{g}$ iron $\mathrm{ml}^{-1}$ in the medium; with $\mathrm{I} \cdot 0 \mu \mathrm{g}$ iron $\mathrm{ml}^{-1}$ (giving ironsufficient growth) the amount of exochelin produced was less than $0.1 \%$ of the maximum level. Using ion-exchange chromatography at least six exochelins were recovered from culture filtrates. The major compound, constituting about $60 \%$ of the total, was isolated, purified and partially characterized. It solubilized iron from inorganic and organic forms, stimulated growth of $M$. smegmatis in serum, was freely diffusible in both its ferri and desferri forms, and transferred the chelated iron to cells at a rate which was independent of its concentration.
\end{abstract}

\section{INTRODUCTION}

The solubility of inorganic iron in aerobic conditions and at neutral $\mathrm{pH}$ values is about $10^{-15}$ M (Sillen \& Martell, I964). This concentration of dissolved iron is too low to make it accessible to living organisms. Therefore the solubilization of iron is essential and most micro-organisms produce specific agents for this purpose (Neilands, 1974). In mycobacteria, iron was originally thought to be solubilized by salicylic acid which is secreted into the extracellular medium (Ratledge \& Winder, 1962). However salicylate fails to hold iron in solution in the presence of phosphate and hence, in growth medium containing phosphate, iron chelation must be achieved by some other compound (Ratledge et al., 1974). Although mycobactin (see Snow, 1970) has been suggested for this role (Kochan, 1973), its insolubility in water, lack of diffusibility in aqueous environments and inability to chelate iron from precipitated or colloidal forms militates against this view. We have consequently searched for and discovered a new type of compound, exochelin, which seems to be the true solubilizer (Macham, Ratledge \& Nocton, 1975).

Exochelins occur extracellularly and accumulate if growth is iron-deficient; a preliminary account of their detection in cultures of $M$. smegmatis and $M$. bovis BCG has appeared (Macham \& Ratledge, 1975) and an account of the probable role of the latter exochelin (exochelin MB) has been published (Macham et al., I975). The exochelin from $M$. smegmatis (exochelin MS) differs from that from M. bovis BCG (exochelin MB) in that it is not extracted by organic solvents. This property has hampered its purification and examination.

In this paper we present evidence for the existence of iron-binding compounds in culture filtrates of $M$. smegmatis together with procedures for their isolation, separation and puri-

* Present address: Glasgow College of Technology, Glasgow. 
fication. We also show how these compounds solubilize iron both from inorganic sources and from organic forms such as ferritin, which may be a source of iron for mycobacteria growing in vivo, and then transfer the iron to the organism.

\section{METHODS}

Organism and growth. Mycobacterium smegmatis $\mathrm{NCIB} 8548$ was grown in $100 \mathrm{ml}$ iron-deficient medium in $250 \mathrm{ml}$ conical flasks with shaking as previously described (Ratledge \& Hall, I97I). Iron was added at 0.05 $\mu \mathrm{g} \mathrm{ml}^{-1}$ unless stated otherwise. Harvesting of cultures, and estimations of bacterial dry wt and mycobactin were as previously described (Ratledge et al., 1974; Ratledge \& Marshall, 1972).

Estimation of total exochelin MS. To assay exochelin in growth media, the bacteria were removed by filtering through Whatman GF/A paper or, for small volumes, through $0.45 \mu \mathrm{m}$ pore-size membranes. A saturated solution of $\mathrm{FeCl}_{3}$ was added dropwise to the filtrates until the formation of an orange complex was complete and adding further $\mathrm{FeCl}_{3}$ resulted in a precipitate. The excess iron was removed by filtering through a $0.45 \mu \mathrm{m}$ pore-size membrane. The $E_{430}$ of the filtrate was measured against spent growth medium to which no iron had been added. Uninoculated medium to which $\mathrm{FeCl}_{3}$ had been added gave very low $(<0.0 \mathrm{I})$ extinctions. The $E_{1 \mathrm{~cm}}^{1 \%}$ value of an aqueous solution of purified ferri-exochelin (fraction 3 , see below) has been provisionally calculated as 23 (L.P. Macham, unpublished work). This value was used to calculate concentrations of exochelin when required.

Isolation and purification of exochelin MS. Growth medium ( $\mathrm{I}$ to 21 ) containing the maximum achievable concentration of exochelin was treated with $\mathrm{FeCl}_{3}$ and filtered through Whatman no. I paper. The medium was passed through a $70 \times 30 \mathrm{~mm}$ column of Zerolit 225 (SRC I6) sulphonic acid ion-exchange resin at about $2 \mathrm{ml} \mathrm{min}^{-1}$. After washing the column with water (about $100 \mathrm{ml}$ ) the exochelin was eluted with I Maq. $\mathrm{NH}_{4} \mathrm{OH} / \mathrm{NH}_{4} \mathrm{Cl}$ buffer, $\mathrm{pH} 9 \cdot 5$, at about 5 to $10 \mathrm{ml} \mathrm{min}{ }^{-1}$. The orange complex was readily eluted and, after drying in vacuo, was dissolved in the minimum of water, de-salted by passing through Sephadex G-IO $(250 \times 10 \mathrm{~mm}$ column) and the eluate was evaporated to $\mathrm{I}$ to $2 \mathrm{ml}$. This preparation is referred to as 'purified but unfractionated material'.

Fractionation of the components of exochelin was by chromatography on a sulphonic acid ion-exchange resin (Bio-Rad, AG 50W-X4, 200 to 400 mesh, $\mathrm{NH}_{4}{ }^{+}$form; $400 \times 25 \mathrm{~mm}$ column) using a gradient of $0 . \mathrm{I} \mathrm{M}-$ $\mathrm{NH}_{4} \mathrm{OH} /$ acetic acid at $\mathrm{pH} 6 \cdot 0$ to $\mathrm{r} \cdot 0 \mathrm{M}-\mathrm{NH}_{4} \mathrm{OH} /$ acetic acid at $\mathrm{pH} 9 \cdot 0$. The eluate was monitored con tinuously at $436 \mathrm{~nm}$ (Altex Flowcell model I52; Altex Scientific Inc., Berkeley, California, U.S.A.) and 2.5 $\mathrm{ml}$ fractions were collected automatically. The six fractions containing iron-binding compounds (see Fig. 5) were individually pooled, evaporated to dryness, dissolved in water $(2 \mathrm{ml})$, de-salted as above and the coloured eluates were evaporated to $2 \mathrm{ml}$.

The major fraction (no. 3, Fig. 5) was separated into two components by ion-exchange chromatography as above using a gradient of $0 . \mathrm{I}$ to $\mathrm{I} \cdot 0 \mathrm{M}-\mathrm{NH}_{4} \mathrm{OH} /$ acetic acid buffer, $\mathrm{pH}$ 10.0. Each component was isolated and de-salted as above.

Preparation of desferri-exochelin and ${ }^{55} \mathrm{Fe}$-exochelin. To $4 \mathrm{ml}$ of a solution of ferri-exochelin (either purified individual fractions or a mixture) in water (about $2.5 \mathrm{mg} \mathrm{ml}^{-1}$ ), was added an excess of 8-hydroxyquinoline and $4 \mathrm{ml}$ methanol. The mixture was shaken, then stood for about $2 \mathrm{~h}$ at $22^{\circ} \mathrm{C}$ to allow complete formation of green ferri-8-hydroxyquinoline which was extracted into redistilled chloroform. The remaining solution of desferri-exochelin was evaporated to dryness in an 'iron-free' flask (see Ratledge \& Hall, 197I). The solid was taken up in $\mathrm{I} \mathrm{ml}$ of a solution of ${ }^{55} \mathrm{FeCl}_{3}$ containing iron at the final specific activity required. ${ }^{55} \mathrm{FeCl}_{3}$, sp.act. about $10 \mathrm{mCi}(\mathrm{mg} \mathrm{Fe})^{-1}$, in $0 . \mathrm{I} \mathrm{M}-\mathrm{HCl}$ was from The Radiochemical Centre, Amersham.] After standing at $22{ }^{\circ} \mathrm{C}$ for a further $2 \mathrm{~h}$, the ${ }^{55} \mathrm{Fe}$-exochelin was separated from excess ${ }^{55} \mathrm{FeCl}_{3}$ by passage through Sephadex G-10 ( $300 \times 25 \mathrm{~mm}$ column).

Concentrations of desferri-exochelin were calculated by titrating solutions of it with dilute $\mathrm{FeCl}_{3}$, measuring $E_{430}$ and assuming an $E_{1 \mathrm{~cm}}^{1 \%}$ value of 23 . Concentrations of ${ }^{55} \mathrm{Fe}$-exochelin were calculated as mol $\mathrm{ml}^{-1}$ from the specific activity of the original solution of ${ }^{55} \mathrm{FeCl}_{3}$. These concentrations agreed well with those determined by measuring the $E_{430}$ of such solutions, assuming a I:I binding of iron to exochelin.

Electrophoresis of exochelins and their subsequent detection. Exochelins, in the ferri form, were applied to Whatman no. I paper $(600 \times 100 \mathrm{~mm})$ and separated by electrophoresis at $3 \mathrm{kV}$ for 45 to $80 \mathrm{~min}$ using either O.I M-acetic acid/sodium acetate buffer, $\mathrm{pH} 4.0$, or 0.1 M-borate buffer, $\mathrm{pH} 9.2$ or 10.0. Although ferriexochelins were usually visible, their colour was increased about fivefold by spraying the dried paper with an aqueous solution of $2 \%(\mathrm{w} / \mathrm{v}) 2,2^{\prime}$-bipyridyl containing $2 \%(\mathrm{w} / \mathrm{v})$ thioglycollic acid. (This reagent reduces the $\mathrm{Fe}^{\mathrm{III}}$ bound to exochelin to $\mathrm{Fe}^{\mathrm{II}}$ which then forms an intense, stable, red complex with the bipyridyl.) For exochelins containing ${ }^{55} \mathrm{Fe}$, the electrophoretogram was cut into $5 \mathrm{~mm}$ strips at right angles to the direction of migration; each strip was placed in a scintillation vial with $0.5 \mathrm{ml}$ water and left at $3{ }^{\circ} \mathrm{C}$ for $16 \mathrm{~h}$ before adding seintillant and counting (see below). 
Iron in diffusion capsules and diffusion experiments. The ability of exochelin to solubilize iron was measured in diffusion capsules ( $42 \times 22 \mathrm{~mm}$ o.d.; LH Engineering, Stoke Poges, Buckinghamshire) used as previously described (Macham et al., I975). Iron, both as $\mathrm{FePO}_{4}$ and ferritin, was completely retained within the capsule when incubated in uninoculated medium at $37^{\circ} \mathrm{C}$ for 5 days (Macham et al., 1975). Ferritin (equine spleen, grade B) was from Calbiochem.

For dialysis experiments, Visking tubing $\left(6 \mathrm{~mm}\right.$ diam.) was filled with $\mathrm{I} \mathrm{ml}$ of either ${ }^{55} \mathrm{Fe}$-exochelin $\left[46 \mu \mathrm{g} ; 4.3 \times 10^{5}\right.$ c.p.m. $\left.\mu \mathrm{g}^{-1}\right]$ or ${ }^{55} \mathrm{FePO}_{4}\left[50 \mu \mathrm{g} \mathrm{Fe} ; 8.8 \times 10^{4}\right.$ c.p.m. $\left.(\mu \mathrm{g} \mathrm{Fe})^{-1}\right]$ and immersed in $15 \mathrm{ml} 50 \mathrm{~mm}-$ $\mathrm{KH}_{2} \mathrm{PO}_{4}$ buffer, $\mathrm{pH} 7 \cdot 2$, containing $0.5 \%(\mathrm{w} / \mathrm{v})$ cetyl trimethylammonium bromide (to prevent bacterial growth). With ${ }^{55} \mathrm{FePO}_{4}$, desferri-exochelin at various concentrations was added to the external buffer. Incubation was at $25^{\circ} \mathrm{C}$ with gentle shaking; samples $(0.5 \mathrm{ml})$ were taken periodically by syringe and ${ }^{55} \mathrm{Fe}$ was counted as detailed below.

Solubilization of iron from ferritin. Ferritin (1 $\mathrm{mg}$ ) in $\mathrm{Io} \mathrm{ml}$ water was shaken with desferri-exochelin $\left(225 \mu \mathrm{g} \mathrm{ml}^{-1}\right)$ at $4{ }^{\circ} \mathrm{C}$ (to prevent bacterial growth). Samples $(0.5 \mathrm{ml})$ were ultra-filtered through a membrane with a cut-off at 10000 daltons (membrane PM 10; Amicon, High Wycombe, Buckinghamshire) and the $E_{430}$ of the filtrates were determined. At the end of the experiment the remaining ferritin was chromatographed through Sephadex G-50 to determine if any degradation had occurred.

Growth of $M$. smegmatis in serum. Duplicate $30 \mathrm{ml}$ tissue-culture flasks (A/S Nunc, Denmark) containing $3 \mathrm{ml}$ undiluted sterile neo-natal calf serum (Flow Laboratories, Irvine, Scotland) were inoculated with $0.5 \mathrm{ml}$ of a suspension of $M$. smegmatis $\left(E_{600}^{1 \%} 0 \cdot \mathrm{I}\right)$. Purified but unfractionated desferri-exochelin MS, also sterilized by membrane-filtration, was added immediately before inoculation to give $30 \mu \mathrm{g} \mathrm{ml}^{-1}$. The flasks were incubated without shaking at $37^{\circ} \mathrm{C}$ and examined daily.

Uptake of iron from ${ }^{55} \mathrm{Fe}$-exochelin $\mathrm{MS}$ into $\mathrm{M}$. smegmatis. Initial rates of iron uptake into washed suspensions of 3-day-old iron-deficient $\left(0.05 \mu \mathrm{g} \mathrm{ml}^{-1}\right)$ cultures of $M$. smegmatis were assayed in a buffer solution containing $50 \mathrm{mM}-\mathrm{KH}_{2} \mathrm{PO}_{4} / \mathrm{NaOH}(\mathrm{pH} 7 \cdot \mathrm{I}), \mathrm{I} \cdot 7 \mathrm{mM}-\mathrm{Mg}^{2+}, 7 \mu \mathrm{M}-\mathrm{Zn}^{2+}$ and $\mathrm{I} \cdot 8 \mu \mathrm{M}-\mathrm{Mn}^{2+}$ in $\mathrm{I} \cdot 75 \mathrm{ml}$. This buffer was pre-incubated for $5 \mathrm{~min}$ in $25 \mathrm{ml}$ Erlenmeyer flasks in a shaking water bath at $25{ }^{\circ} \mathrm{C}$. The washed suspension [0.25 ml; about $50 \mathrm{mg}^{2}$ dry wt $\mathrm{ml}^{-1}$ in $0.85 \%(\mathrm{w} / \mathrm{v}) \mathrm{NaCl}$ containing $\mathrm{r} \%(\mathrm{w} / \mathrm{v})$ Tween 80 ] was added and pre-incubation was continued for a further Io min. ${ }^{55} \mathrm{Fe}-$ Exochelin fraction $3 \mathrm{~A}(0.25 \mathrm{ml})$, prewarmed to $25{ }^{\circ} \mathrm{C}$, was then added by syringe. (The volume of the assay mixture was increased when more samples were required.) Using an automatic pipette, samples $(0.5 \mathrm{ml})$ were run into a modified Millipore Swinnex-25 filter unit holding a Whatman GF/A filter disc $(25 \mathrm{~mm} \mathrm{diam}$.) and $5 \mathrm{ml}$ distilled water at room temperature. Suction was immediately applied to the filter disc to drain it completely. The filter was washed with a further $5 \mathrm{ml}$ distilled water, removed immediately, placed in a glass scintillation vial and dried overnight in an oven at $108^{\circ} \mathrm{C}$. Soluene $100(0.5 \mathrm{ml}$; Packard Instruments) was added to each vial before incubating at $60^{\circ} \mathrm{C}$ for $5 \mathrm{~h}$ to digest the bacteria. Acetic acid $(0.4 \mathrm{ml})$ and scintillation fluid (10 $\mathrm{ml}$ ) were added to each vial before counting (see below). As these experiments involved only soluble iron, no precipitated iron was trapped on any of the apparatus.

Radioactive counting. The radioactivity in samples containing ${ }^{55} \mathrm{Fe}$ was measured as previously described (Ratledge et al., 1974). Standard solutions of ${ }^{55} \mathrm{Fe}$ were used to calculate the actual amounts of iron, and interanl standard corrections for quenching were made where appropriate.

\section{RESULTS AND DISCUSSION}

\section{Evidence for the occurrence of iron-solubilizing compound(s) in the culture filtrates of $M$. smegmatis}

Production of exochelin during growth. Exochelin was secreted into the medium by irondeficient cultures of $M$. smegmatis during active growth (Fig. I) and stopped when growth reached the stationary phase. The production of mycobactin also began at about $30 \mathrm{~h}$ but continued into the stationary phase. There was no indication that exochelin was metabolized in stationary phase cultures. Assuming an $E_{1 \mathrm{~cm}}^{1 \%}$ value of 23 for ferri-exochelin, the maximum concentration of exochelin here corresponds to about $50 \mu \mathrm{g} \mathrm{ml}^{-1}$.

Effect of iron concentration on exochelin production. The production of exochelin depended on the concentration of iron in the growth medium (Fig. 2). In $72 \mathrm{~h}$ cultures the maximum production of exochelin occurred in medium to which $0.03 \mu \mathrm{g} \mathrm{Fe} \mathrm{ml} \mathrm{m}^{-1}$ had been added. We could not detect exochelin in culture media containing $\mathrm{I} \mu \mathrm{g} \mathrm{Fe} \mathrm{ml}^{-1}\left(E_{430}\right.$ $<0.0 \mathrm{I})$ nor in I 1 of iron-sufficient $\left(2 \mu \mathrm{g} \mathrm{Fe} \mathrm{ml}^{-1}\right)$ growth medium after concentrating it to Io $\mathrm{ml}$; when $0.05 \mu \mathrm{g} \mathrm{Fe} \mathrm{ml}{ }^{-1}$ was added to the same batch of medium the organism secreted 


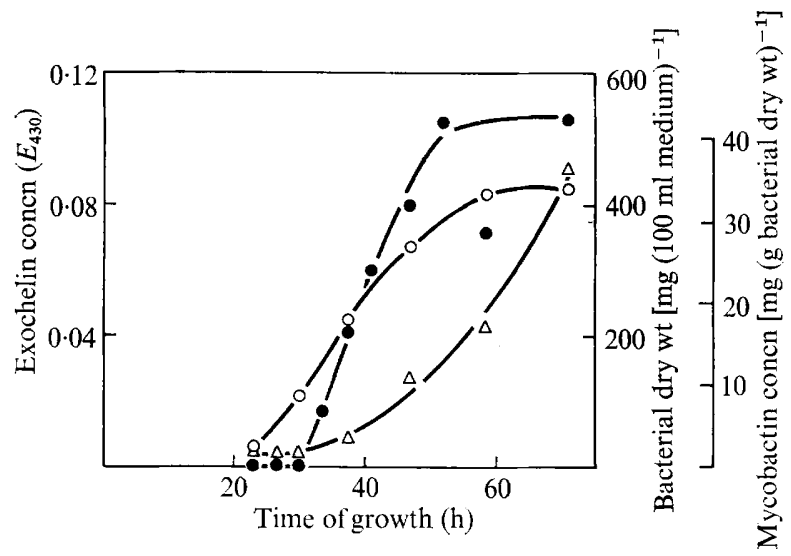

Fig. I. Production of exochelin MS during growth. Iron-deficient cultures of $M$. smegmatis were grown in shaken flasks. At intervals, entire flasks were taken for estimations of exochelin (O), bacterial dry wt $(O)$ and mycobactin $(\triangle)$.

Table I. Growth and exochelin production by M. smegmatis with $\mathrm{FeCl}_{3}$ in the medium or contained within diffusion capsules

\begin{tabular}{|c|c|c|c|}
\hline Culture condition & Iron added $\left(\mu \mathrm{g} \mathrm{ml}^{-1}\right)$ & $\begin{array}{l}\text { Bacterial dry wt } \\
\text { after } 5 \text { days } \\
{\left[\mathrm{mg}(100 \mathrm{ml})^{-1}\right]}\end{array}$ & Exochelin* $\left(E_{430}\right)$ \\
\hline \multirow[t]{3}{*}{ No diffusion capsule } & 0 & 138 & 0.045 \\
\hline & 0.05 & 528 & 0.094 \\
\hline & $2 \cdot 0$ & 788 & 0.002 \\
\hline \multirow[t]{3}{*}{ Diffusion capsule } & o & $29 I$ & $0 \cdot 108$ \\
\hline & 0.05 & 650 & $0 \cdot 112$ \\
\hline & $2 \cdot 0$ & 753 & 0.072 \\
\hline
\end{tabular}

exochelin giving (ferri form) an $E_{430}$ of 0.12 . The concentration of exochelin during ironsufficient growth must therefore have been at least I000-fold less than during iron-deficient growth. (Mycobactin formation is repressed in iron-sufficient cells to about $0.05 \%$ of the amount in iron-deficient cells.)

For mycobacteria growing in vivo, iron may be available only from compounds like ferritin and transferrin. When ferritin was substituted for $\mathrm{FeCl}_{3}$ in the growth medium, maximum production of exochelin occurred after 5 days (Fig. 3). Ferritin between 2.5 and Io $\mu \mathrm{g} \mathrm{ml}^{-1}$ produced the greatest concentration of exochelin [about $\mathrm{I} 50 \mu \mathrm{g} \mathrm{ml}^{-1}$ ], and also of mycobactin in the cells [about $37 \mu \mathrm{g}$ (mg bacterial dry wt) ${ }^{-1}$ ]. Even when the concentration of ferritin was very high $\left(50 \mathrm{mg} \mathrm{ml}^{-1}\right)$, exochelin and mycobactin were still produced in concentrations higher than usual for iron-sufficient conditions. Mycobacteria thus apparently have difficulty in removing iron from ferritin because they need to produce high concentrations of iron-chelating agents.

Diffusion capsule experiments. When ferritin, as the source of iron, was contained in a diffusion capsule, exochelin production was greatest (about $220 \mu \mathrm{g} \mathrm{ml}^{-1}$ ) at the mid-point of growth (Fig. 4). When the same amount of ferritin was dispersed in the growth medium, exochelin production was $10 \%$ of about this value. Without ferritin a limited amount of growth still occurred due to the traces of iron associated with the empty capsule.

Similar results (Table I) were obtained using $\mathrm{FeCl}_{3}$ either in the medium or withheld from the cells in capsules. (Although iron is added to cultures as $\mathrm{FeCl}_{3}$, it quickly precipitates as ferric phosphate.) Exochelin was produced only when iron was not readily avail- 


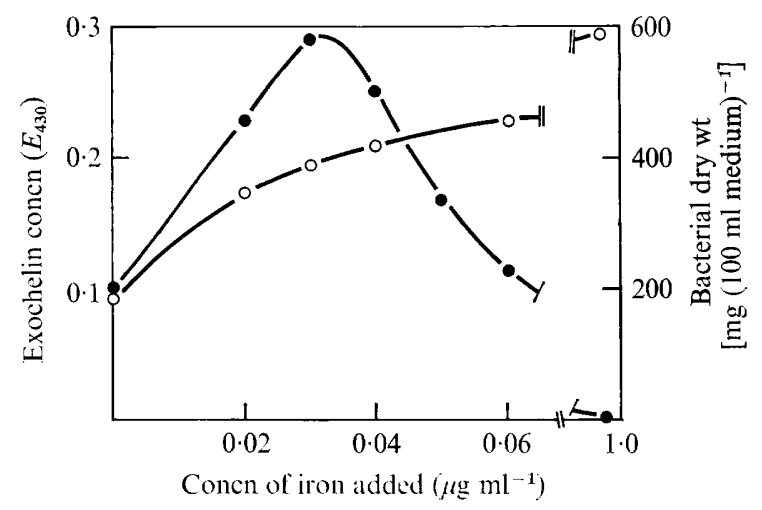

Fig. 2. Effect of iron concentration on exochelin production and growth. $\mathrm{Fe}^{3^{+}}$was added at the concentrations indicated to cultures of $M$. smegmatis growing in shaken flasks. After 3 days growth, exochelin concentration in the medium $(O)$ and bacterial dry wt $(\bigcirc)$ were determined. Each point is the average of duplicate determinations.

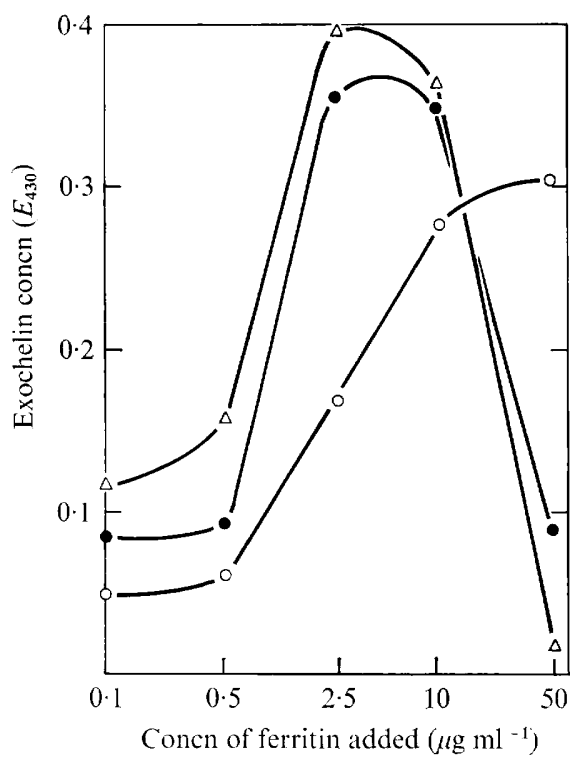

Fig. 3

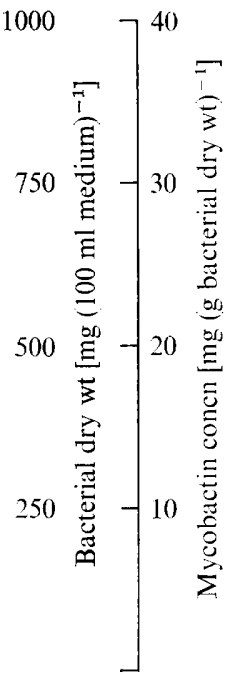

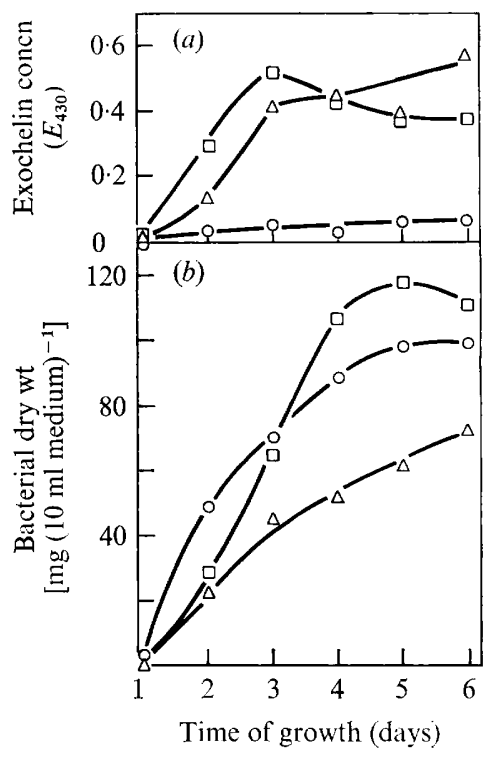

Fig. 4

Fig. 3. Effect of ferritin on growth, exochelin and mycobactin production. Conditions of growth and sampling were as in Fig. 2. After 5 days growth, exochelin concentration (O), bacterial dry wt $(\bigcirc)$ and mycobactin concentration $(\triangle)$ were determined.

Fig. 4. (a) Exochelin production and (b) growth of $M$. smegmatis in the presence of a diffusion capsule: empty $(\triangle)$; containing $5 \mathrm{mg}$ ferritin in I $\mathrm{ml}$ growth medium ( $\square$ ); or empty, but with the same amount of ferritin added externally to the capsule $(O)$.

able to cells, either because insufficient iron was added to the medium, or because the iron was in the capsule. When iron was in the capsule, the lag period was prolonged though by the end of the experiments ( 5 days) both cultures had attained similar yields (Table I).

The diffusion capsule experiments, with either ferritin or $\mathrm{FeCl}_{3}$, show that otherwise inaccessible iron can be utilized for growth by the production of a diffusible water-soluble iron-binding compound, exochelin. 

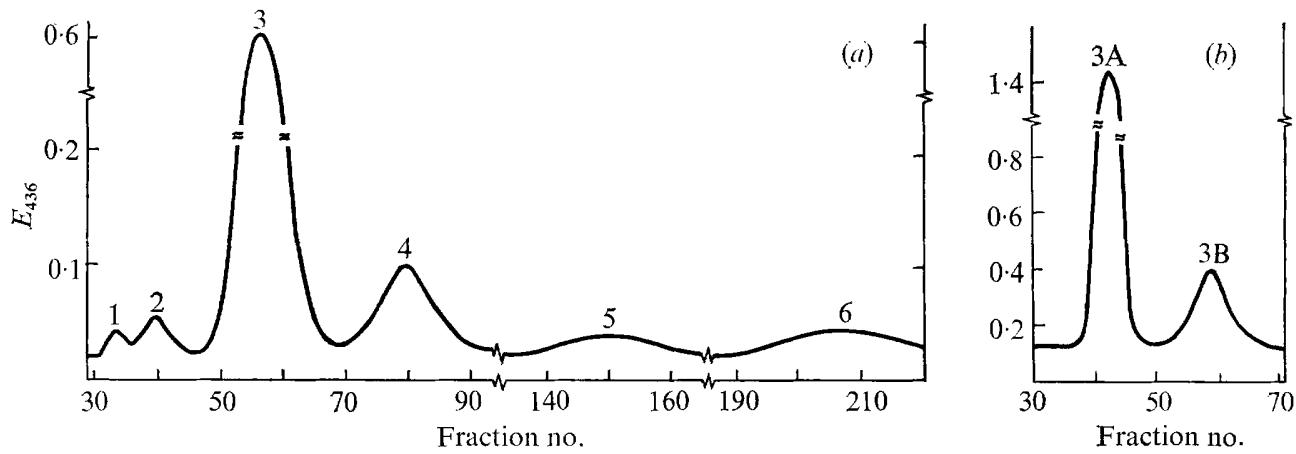

Fig. 5. Fractionation of exochelins (ferri form) by ion-exchange chromatography: (a) using a gradient of $0 . \mathrm{I}$ to $\mathrm{I} \cdot 0 \mathrm{M}-\mathrm{NH}_{4}^{+}, \mathrm{pH} 6.0$ to $9 \cdot 0$, (see Methods); (b) using $0 . \mathrm{I}$ to $\mathrm{I} \cdot 0 \mathrm{M}-\mathrm{NH}_{4}^{+}, \mathrm{pH}$ I0.0. Eluates were monitored continuously at $436 \mathrm{~nm} ; 2.5 \mathrm{ml}$ fractions were collected, and those having an extinction beyond the sensitivity of the photocell were re-determined after dilution.

\section{Isolation and fractionation of the exochelins from the medium of $M$. smegmatis}

Isolation of exochelins. An orange solution of ferri-exochelins was obtained after the initial ion-exchange chromatography and passage through Sephadex G-IO. It had a broad absorption band in the visible region of the spectrum with a $\lambda_{\max }$ at $430 \mathrm{~nm}$ and no absorption in the near ultraviolet region, indicating the absence of conjugation and an aromatic moiety. During the subsequent examination of this solution it became apparent that it was a mixture of iron-binding compounds but it could not be purified by solvent extraction because of its insolubility in any organic solvent. (Even when isolated, exochelin is only slightly soluble in methanol or ethanol.)

Fractionation of exochelins. Ion-exchange chromatography gave six distinct coloured fractions (Fig. 5a). As the major fraction (no. 3), which constituted about $75 \%$ of the total, could be separated into two fractions by electrophoresis with borate buffer at $\mathrm{pH} 10.0$, it was re-chromatographed on the same resin using $\mathrm{NH}_{4} \mathrm{OH} /$ acetic acid at $\mathrm{pH}$ 10.0 (see Methods) to isolate the two components (A and B); fraction A constituted about $80 \%$ of the mixture (Fig. $5 \mathrm{~b}$ ). Each component migrated as a single spot when subjected to electrophoresis at $\mathrm{pH}$ I0.0 and 4.0 ; no contaminating iron-binding compounds were revealed by the bipyridyl/thioglycollic acid spray. Fraction $3 \mathrm{~A}$ was stable for $24 \mathrm{~h}$ in $\mathrm{I} \cdot 0 \mathrm{M}-$ $\mathrm{NH}_{4} \mathrm{OH} /$ acetic acid, $\mathrm{pH}$ I0.0, which were the conditions used to isolate it.

\section{Functions of the isolated exochelins}

In most of the following work the major fraction $3 \mathrm{~A}$ was used to examine the properties of the exochelins though, in some experiments, fraction 3 was used before it was appreciated it was a mixture.

Solubilization of iron by exochelin. At $\mathrm{pH} 7 \cdot 0$ the solubility of free ferric iron is $\mathrm{IO}^{-15} \mathrm{M}$, assuming a solubility product for $\mathrm{Fe}(\mathrm{OH})_{3}$ of $\mathrm{IO}^{-36}$ (Sillen \& Martell, I964). Ferric phosphate has a similar solubility product (Sillen \& Martell, I964). After $\mathrm{FeCl}_{3}$ at $20 \mu \mathrm{g} \mathrm{Fe} \mathrm{ml}^{-1}$ had been held in $50 \mathrm{~mm}$-phosphate buffer or Tris/HCl buffer, $\mathrm{pH} 7 \cdot 2$, for $16 \mathrm{~h}$ to ensure complete precipitation, desferri-exochelin (fraction 3) rapidly solubilized the iron. In addition, however, ferri-exochelins must be readily diffusible to explain the results using diffusion capsules. When ${ }^{55} \mathrm{Fe}$-exochelin (fraction $3 \mathrm{~A}$ ) was held in a dialysis sac immersed in $50 \mathrm{~mm}$ phosphate buffer, $\mathrm{pH} 7 \cdot 2$, and the whole gently shaken at $25^{\circ} \mathrm{C}$, equilibration of iron took I $5 \mathrm{~h}$, being $90 \%$ complete within $5 \mathrm{~h}$. When the source of iron in the dialysis sac was changed to an insoluble form $\left({ }^{55} \mathrm{FePO}_{4}\right)$ and desferri-exochelin (fraction $3 \mathrm{~A}$ ) was added externally, the amount of, and rate of appearance of, soluble ${ }^{55} \mathrm{Fe}$ in the external medium was proportional to the amount of desferri-exochelin added (Fig. 6). 


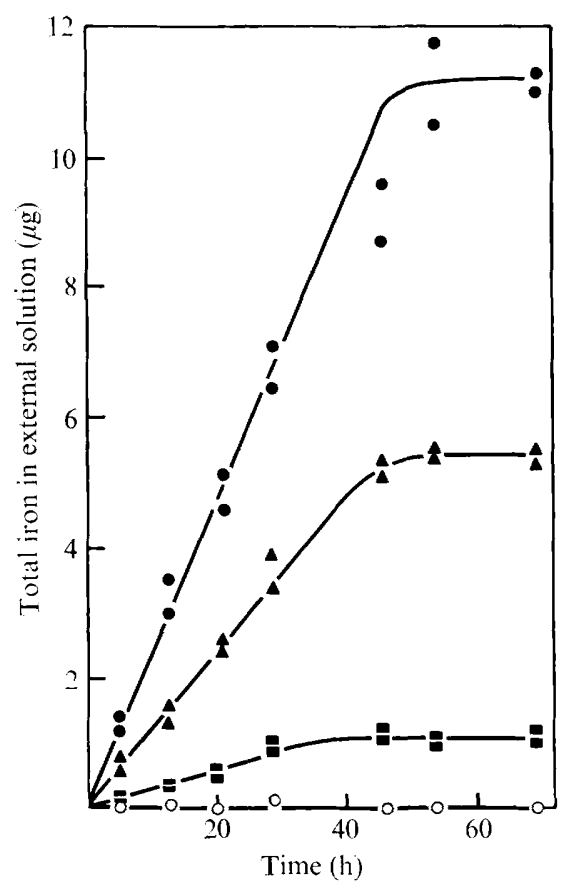

Fig. 6. Solubilization of iron from ${ }^{55} \mathrm{FePO}_{4}\left(50 \mu \mathrm{g} \mathrm{Fe} ; 0.04 \mu \mathrm{Ci}(\mu \mathrm{g} \mathrm{Fe})^{-1} ; \mathrm{I} \mathrm{ml}\right)$ contained in a dialysis sac immersed in $15 \mathrm{ml} 50 \mathrm{mM}^{-} \mathrm{KH}_{2} \mathrm{PO}_{4}$ buffer, $\mathrm{pH} 7.2$, containing $0.5 \%$ cetyl trimethylammonium bromide and desferri-exochelin (fraction $3 \mathrm{~A}$ ) at $\left(\mu \mathrm{g} \mathrm{ml}^{-1}\right): 13.3(\mathbf{O}) ; 6.7(\mathbf{\Delta}) ; \mathrm{I} \cdot 3(\boldsymbol{\boldsymbol { c }})$; or o $(\mathrm{O})$. Samples $(0.5 \mathrm{ml})$ were taken by syringe and ${ }^{55} \mathrm{Fe}$ was counted as in Methods. The mixture was shaken continuously at $25^{\circ} \mathrm{C}$.

When desferri-exochelin was shaken with an aqueous solution of ferritin at $4{ }^{\circ} \mathrm{C}$, ferriexochelin was steadily formed as shown by the increase in $E_{430}$ of samples which had been ultra-filtered. After $55 \mathrm{~h}$ more than $90 \%$ of the exochelin was int the ferri form and the ferritin remained undegraded.

Thus, exochelin can rapidly solubilize iron. When purified but unfractionated desferriexochelin (at $100 \mu \mathrm{g} \mathrm{ml}^{-1}$ ) was added to iron-deficient cultures of $M$. smegmatis, the growth rate was not significantly increased nor was the lag period shortened. Presumably exochelin is synthesized early enough for cultures unsupplemented with exogenous exochelin not to be retarded and thus iron solubilization is not a growth-limiting process.

Ability of exochelin MS to overcome the bacteriostatic effect of serum. Mycobacterium smegmatis grew poorly in undiluted calf serum but was strongly stimulated by purified but unfractionated desferri-exochelin at $30 \mu \mathrm{g} \mathrm{ml}^{-1}$.

The bacteriostatic effect of serum is considered to be due to the iron-binding protein, transferrin, withholding iron from the bacteria (Kochan, 1973; Bullen, Rogers \& Griffiths, I974). Exochelin must, therefore, be able to sequester iron from this protein and thus stimulate growth of $M$. smegmatis. Serum is rich in iron, but without added exochelin growth is extremely slow as the concentration of free iron is virtually nil and exochelin biosynthesis is therefore severely repressed (see Fig. 2). It takes some time before the bacteria are able to overcome this situation. [A similar repression of mycobactin biosynthesis has also been noted at very low concentrations of iron (Ratledge \& Hall, 197I).]

Uptake of iron from ${ }^{55} \mathrm{Fe}$-exochelin by washed suspensions. ${ }^{55} \mathrm{Fe}$ was taken up by washed suspensions of $M$. smegmatis from ${ }^{55} \mathrm{Fe}$-exochelin (fraction $3 \mathrm{~A}$ ) over the range 0.8 to 8.0 $\mathrm{nmol} \mathrm{Fe} \mathrm{ml} \mathrm{m}^{-1}$ at a rate which was independent of its concentration (Fig. $7 a$ ). However the total amount of ${ }^{55} \mathrm{Fe}$ taken up was dependent on the external concentration (Fig. $7 \mathrm{~b}$ ). If the 

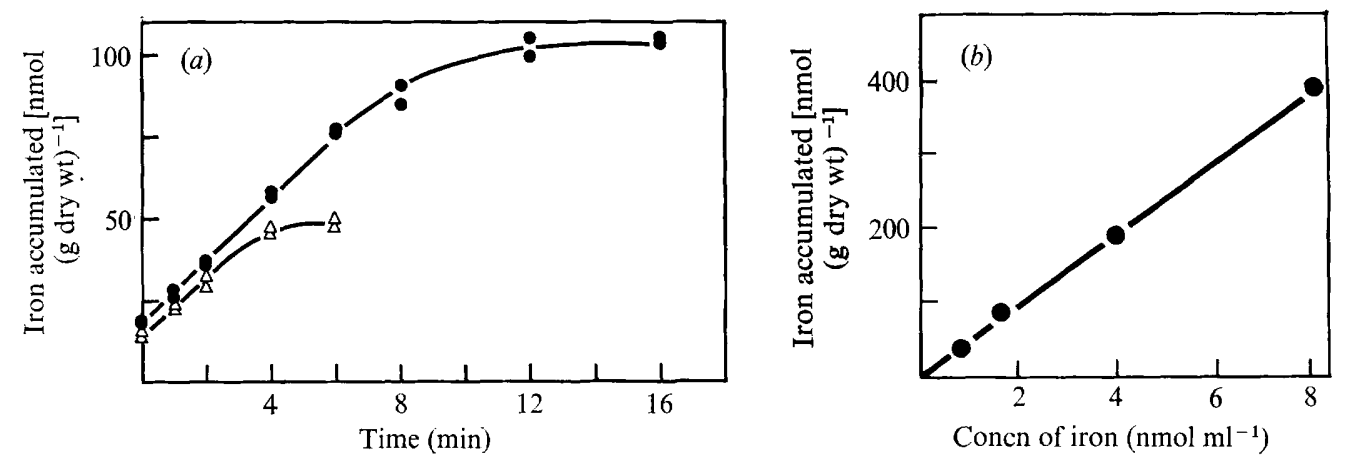

Fig. 7. Uptake and accumulation of iron from ${ }^{55} \mathrm{Fe}$-exochelin (fraction $3 \mathrm{~A}$ ) by a washed suspension of $M$. smegmatis grown in iron-deficient medium. (a) Rate of uptake with ${ }^{55} \mathrm{Fe}$-exochelin at $0.8(\triangle)$ or $\mathbf{1} \cdot 6(\mathrm{O}) \mathrm{nmol} \mathrm{Fe} \mathrm{ml}^{-1}$; duplicate samples were taken. (b) Relationship between the amount of iron accumulated, corrected for zero-time absorption, and the concentration of iron in the extracellular assay fluid.

intracellular volume of $M$. smegmatis is, say, $2 \mathrm{ml}$ ( $\mathrm{g}$ dry wt) ${ }^{-1}$ (a typical value for bacteria; see, for example, Midgley \& Dawes, 1973), the amount of iron accumulated is concentrated 23 -fold. The rate of iron uptake from $6 \mu \mathrm{M}^{-55} \mathrm{Fe}$-exochelin was not increased by salicylic acid at $70 \mu \mathrm{M}$ or I mM.

Uptake of iron from ferri-exochelin therefore occurs readily and rapidly even in the presence of competing ions such as phosphate.

\section{The function of the exochelins}

Although a wide variety of microbial iron-binding compounds are now known (Neilands, I974), most of the work on their physiological role has been on their participation in the transport of iron into the cell. Little or no attempt has been made to show that these compounds can solubilize iron and yet this is the first essential step in the acquisition of iron by any micro-organism. The exochelins we have isolated solubilize iron from inorganic sources such as $\mathrm{Fe}(\mathrm{OH})_{3}$ and $\mathrm{FePO}_{4}$ and from organic sources such as ferritin and presumably transferrin; they are freely diffusible in both the ferri and desferri forms and they present the iron to the cells in a readily-assimilable manner. In short, they perform all the initial steps in the acquisition of iron for growth of $M$. smegmatis in both natural and laboratory environments.

There may be a family of exochelins all fulfilling the same function. Exochelin MS, fraction $3 \mathrm{~A}$, contains $3 \mathrm{~mol} \epsilon-N$-hydroxylysine, probably each acylated on the $\epsilon-\mathrm{N}$ atom, plus $\beta$-alanine and threonine (L.P. Macham \& M. C. Stephenson, unpublished work), and modifications might be made to the molecule without changing its essential properties. The exochelins from $M$. bovis BCG, which contain a salicylate moiety and are distinguished from those of $M$. smegmatis by their solubility in chloroform, fulfil an analogous physiological role (Machan et al., 1975). L- $\alpha$-Asparaginyl-L- $\alpha$-( $N$-hydroxy)-asparagine recently isolated from a strain of $M$. avium (McCullough \& Merkal, 1976) is possibly yet another example of an exochelin molecule though its physiological properties have yet to be studied. The mechanism by which iron is transferred from ferri-exochelin into the cell remains uncertain. Transport of iron across the lipoidal boundary layers of the bacteria is mediated by mycobactin when iron is presented to the cell as ferric salicylate (Ratledge \& Marshall, 1972). Whether the same occurs when a ferri-exochelin is used has yet to be established. Ferric salicylate, unlike ferri-exochelin, can only operate in the absence of competing ions such as phosphate or citrate (Ratledge et al., 1974) and a role for it beyond that as a precursor of mycobactin has yet to be ascribed (Ratledge, 1976). 
Sandra Dews, Jenny Nocton and Jen Beaumont are thanked for skilled technical assistance. This work was supported by research grants from the Science Research Council.

\section{REFERENCES}

Bullen, J. J., Rogers, H. J. \& GRIFFiths, E. (I974). Bacterial iron metabolism in infection and immunity. In Microbial Iron Metabolism, pp. 51755I. Edited by J. B. Neilands. New York: Academic Press.

Kochan, I. (1973). The role of iron in bacterial infections, with special consideration of hosttubercule bacillus interaction. Current Topics in Microbiology and Immunology 60, I-30.

Macham, L. P. \& Ratledge, C. (1975). A new group of water-soluble iron-binding compounds from mycobacteria: the exochelins. Journal of General Microbiology 89, 379-382.

Macham, L. P., Ratledge, C. \& Nocton, J. C. (1975). Extracellular iron acquisition by mycobacteria: role of the exochelins and evidence against the participation of mycobactin. Infection and Immunity 12, 1242-I25I.

McCullough, W. G. \& Merkal, R. S. (1976). Ironchelating compound from Mycobacterium avium. Journal of Bacteriology 128, I 5-20.

Midgley, M. \& Dawes, E. A. (I973). The regulation of glucose transport and methyl $\alpha$-glucoside in Pseudomonas aeruginosa. Biochemical Journal I32, I 4 I-I 54 .

NeILANDS, J. B. (editor) (1974). Microbial Iron Metabolism. New York: Academic Press.
RATledge, C. (I976). The physiology of the mycobacteria. Advances in Microbial Physiology 13, I $15-244$.

RATLEDGE, C. \& HALL, M. J. (I97I). Influence of metal ions on the formation of mycobactin and salicylic acid in Mycobacterium smegmatis grown in static culture. Journal of Bacteriology 108, 3I 2-3I9.

RatledGe, C. \& Marshall, B. J. (I972). Iron transport in Mycobacterium smegmatis: the role of mycobactin. Biochimica et biophysica acta $\mathbf{2 7 9}$, 58-74.

RATledge, C. \& Winder, F. G. (I962). The accumulation of salicylic acid by mycobacteria during growth on an iron-deficient medium. Biochemical Journal 84, 50I-506.

Ratledge, C., Macham, L. P., Brown, K. A. \& MARSHALL, B. J. (1974). Iron transport in $\mathrm{Myco-}$ bacterium smegmatis: a restricted role for salicylic acid in the extracellular environment. Biochimica et biophysica acta 372, 39-5I.

Sillen, L. G. \& Martell, A. E. (1964). Stability Constants of Metal-ion Complexes, Special Publication no. I7. London: The Chemical Society.

SNow, G. A. (1970). Mycobactins: iron-chelating growth factors from mycobacteria. Bacteriological Reviews 34, 99-125. 